\title{
专升本转型期如何推进思政教育工作创新 一以上海立达学院升本为例
}

How to Promote the Innovation of Ideological and Political Education in the Transition Period of Junior College Upgraded to Undergraduate Degree

— Taking the Upgrade to Undergraduate of Shanghai Lida University as an Example

康娟

Juan Kang

\section{上海立达学院}

中国・上海 201600

Shanghai Lida University,

Shanghai, 201600, China

基金项目:本文系上海民办高校党建与

思想政治工作研究实践案例类课题立 项, 项目名称:民办专升本高校学生党 员发展典型案例研究; 项目编号: M2019SJ14。
【摘 要】2018 年9月10日, 习近平在全国教育大会上提出的“九个坚持”, 高度概括了新 时代教育改革发展的新思想、新理念、新观点。在上海立达学院专升本转型的重要时期, 要 住机遇、超前布局, 以“九个坚持”作为战略指导思想, 以推进思想政治教育工作的创新。

【Abstract】On September 10, 2018, Xi Jinping put forward the "Nine Persistence" at the National Education Congress, which highly summarized the new ideas, new ideas and new viewpoints of the reform and development of education in the new era. In the important period of the transformation of junior college upgraded to undergraduate degree of Shanghai Lida University, it is necessary to live in opportunities and advance the layout. Taking "Nine Persistence" as the strategic guiding ideology to promote the innovation of ideological and political education work.

【关键词】专升本; 思政工作;创新

【Keywords】promotion; ideological and political work; innovation

[DOI】10.36012/sde.v2i3.1597

\section{1 引言}

2018 年 5 月 16 日教育部下达了《关于同意上海立达学 院备案的批复》, 审批通过了在上海立达职业技术学院的基础 上成立上海立达学院, 首批设置财务管理、国际商务、产品设 计、视觉传达设计、摄影 5 个本科专业, 在这样一个专升本的 重要转型期, 如何推进高校思政工作的创新是一个值得上海 立达学院教育工作者思考的问题。9 月习近平总书记在全国 教育大会上系统的总结了在推进中国在教育改革的进程中要 做到的“九个坚持”, 可以说“九个坚持”是新时代教育改革发 展新思想、新理念、新观点的高度概括, 而要想完成上海立达
学院由专科到本科的转化, 实现产教融合, 走向国际化, 就要 继续牢牢把握教育改革发展的“九个坚持”新思想、新观点、新 论断, 这一思想对于上海立达学院思政教育工作创新也有很 大的启示性作用。

\section{2 坚持把立德树人作为根本任务, 传承 “立人达人”的育人理念}

上海立达学院始终传承“已欲立而立人, 已欲达而达人” 的育人理念,在教师谋求生存、发展的同时也要教会学生学会 生存和发展, 这虽然是传统儒家教育思想, 但是结合当代教育 中“立德树人”的根本任务, 实现传统与现代的融合, 实施养成 教育、成功教育、合格教育也是教育理念的一次创新。 
素质教育 Quality Education

要做到“立德树人”, 首先要加强师德师风建设, 教师要端 正自身、以身作则、为人师表，因为教师不仅仅是人类灵魂的 工程师, 也是学生的行为标杆, 教师的一言一行都对学生产生 很大的影响, 每位教师都要树立远大的职业道德理想, 怀有坚 定地职业道德信念 ${ }^{[1]}$ 。其次, 要“推已及人”, 加强对学生的思 想道德教育, 抓住学生价值观形成、确立的关键时期,进行社 会主义核心价值观教育。在当代的民办高校思政辅导员队伍 中存在一个比较普遍的问题: 辅导员忙于日常学生管理工作 而忽略了对学生的思想政治教育, 大学辅导员是思政教育的 主干力量, “育人为本, 德育为先”, 辅导员要将“德育”贯穿在 思政教育和学生管理工作过程中, 培养学生正确的认识时代 的责任和历史使命。

加强师德师风建设, 可以在全校的师资队伍中进行“师德 标兵”评选,树立典型的师德形象, 要摒弃传统的教师互评互 选的方式, 利用“微信” “微博”等学生喜闻乐见的投票渠道进 行评选, 以此来激励广大教职工自觉地加强自身师德师风修 养。对于学生的“德育”工作,要形成符合当今时代发展的新型 工作思路,过于理论化的学习反而不会起到太大的作用, 要让 学生“在做中学”, 通过实践增强学生的道德认知。

\section{3 坚持深化教育改革创新, 探索“个性化” 的发展模式}

面对升本, 艺术学院召开了教学研讨会, 深入探讨了专科 与本科的差异性,会议总结上海立达学院的属性定位为“应用 型本科”院校, 面对上海立达学院新增的五个本科专业, 既要 区别于专科的教育理念, 主动提升本校的人才培养能力, 在专 科教学的基础上进行扎实的本科教学工作; 也要区别于综合 类大学的本科专业, 实行技能型人才培养模式, 注重专业建 设,形成“重实训”“重情景”的教学形式。

面对“00”后新生, 要在思政教育工作进行过程中做到因 时而进、因势而新,遵循当代学生的成长规律。2019 年 9 月开 学伊始, “00”后走进了大学校园, 他们被称为“网生代”青年, 伴随着“互联网”技术成长, 因此他们在接触信息的过程中呈 现的是“视觉化” “碎片化” “虚拟化”的特点, 随着网络课程的 发展, “碎片化” 的学习也成为获取知识、方法的途径, “碎片 化”学习打破了时间、空间的界限，学生可以在任何时间、地点 进行学习交流。面对这一现状, 在思政教育中也要积极创新,
以系统化教学为主, 碎片化教学为辅, 尝试利用新型网络媒体 为学生提供相对 “视觉化” “虚拟化”的课程资源, 提升学生的 学习兴趣。

面对 “转化·融合・国际” 的发展目标, 在本科课程设置上, 制定海外微留学的必修课程, 在微留学课程之前增设雅思课 程, 为海外学习打下坚实的基础。新生军训结束就开始了英语 浸泡月活动, 形成了浓厚的英语学习氛围; 师资配备上, 聘请 世界优秀教师进行授课, 此外还有国际的大咖来校进行教学 指导; 硬件设施上, 在原有五大实训中心的基础上, 精心建设 了一批本科实训实验室, 并改造部分教室为智慧型、国际型教 室, 以保证本科生的国际化、个性化教学; 学生管理上, 将针对 第一届本科学生, 聘请专职辅导员与导师共同管理, 并在开学 初发放了家校联盟手册,加强家长与学校的沟通。

\section{4 坚持扎根中国大地办教育,构建“交流 互通”的思政工作氛围}

在思政教育工作过程中, 也要坚持“走出去” “引进来” 战 略, 加强民办院校之间的经验交流, 升本后上海立达学院教师 积极参加上海市民办高校组织的思政教育专题培训，在培训 交流的过程中，听取了其他民办本科高校在升本初期的成功 经验, 比如, 上海建桥学院在发展学生党员的过程中开展“低 年级帮扶” “志愿服务” “党史剧”等一系列有意思的活动, 提升 学生党员的积极性。上海立达学院也可以在立足本校实际的 基础上加以借鉴, 形成有特色的党建活动方案。此外, 还提出 了很值得思考的问题: 学生发展为预备党员后积极性减弱, 预 备党员后续教育该如何开展?随着第一届本科生的入校, 上海 立达学院今后也将面临大四学生党员预备期考察以及转正的 问题，通过交流可以提前预想在今后发展过程中会出现的一 些问题,提前发现、提早预防。

习近平总书记强调: 我们要抓住机遇、超前布局。在上海 立达学院专升本的重要机遇下, 学校要践行 “九个坚持”, 从自 身出发做好学生的思政教育工作, 积极探索创新的教育模式, 以更高远的历史站位、更宽广的国际视野、更深遂的战略眼 光, 使大学生思政教育常态化制度化, 最终实现 “转化·融合国际”转型。

\section{参考文献}

[1]赵水根.当代高校思政教育工作的创新方法和途径探索 [J].企 业导报,2016(20):118-119. 